\title{
Study on Negative Regions Problem using Moving Model
}

\author{
H. Gokaya, T. Horii, Y. Hamamatsu, N. Soda, K. Kurihara and M. Kobayashi \\ College of Engineering, Ibaraki University, 4-12-1 Nakanarusawa, Hitachi 316-8511
}

The Preisach model is constructed with some experimental loops that are measured to turn over at any external magnetic field to oppsite maximum one. It is possible to predict relations between magnetization and magnetic field, using the distribution function made from the experimental loops. It can think that the magnitude of distribution function imply the number of magnetic dipole in the magnetics. Therefore, it can expected that all values in the distribution function are positive. However, in the actual distibution function maken from the experimental loops, both areas having positive and having negative exist actually. In this paper, examples of adverse effects because of the large negative regions are shown. Then the moving model is applied as a solution of the problem. Predicted minor loops with the model are good agreement with experimental ones, confirming the effectivity of moving factor decided experimentally.

Key words: magnetic hysteresis, distibution function, Moving model, Preisach model

\section{ムービングモデルによる負領域問題の検討}

\author{
五ヶ谷宏臣・堀井龍夫・浜松芳夫・祖田直也・栗原和美・小林正典 \\ 茨城大学工学部, 日立市中成沢町 4-12-1( ⿳ 316-8511)
}

\section{1. はじめに}

磁性材料を利用した産業製品の応用例は様々な分野に見る ことができ、発電機や変圧器など電力に利用される製品から コンピュータに使用される磁気記録媒体までさまざまな産業 分野で利用されている。これら磁性材料は飽和現象や磁気ヒ ステリシス現象といった複雑な現象を有するためそれらの現 象を正確に把握することが磁性材料の応用分野の重要な課題 となっている。

1935 年、Preisach 氏によって古典プライザッハモデル1) が 提案された。このモデルは、外部磁界のある大きさにおいて 向きを反転する磁気双極子を単位として、さまざまな反転性 質を持った磁気双極子の集合として実際の磁性材料を表現し たものである。このモデルは実験的に一次推移曲線群と呼ば れるいくつかのマイナーループを測定することによって複雑 なマイナーループを予測可能とした点で優れたものであるが、 一方で問題点も存在する。このモデルには合同特性と名づけ られた特徵があり、同一磁界間に存在するマイナーループは いずれの磁化位置でも同一となる欠点を有している。また、一 次推移曲線群から作成されるプライザッハ分布関数図表の值 は、本来、磁気双極子の数を表しているので正の值であるべ きと考えられるが、実験的に求めた図表上では負の值を持つ 領域が存在する。

これらの問題、特に合同特性を解決するため、これまで数々 の改良モデルが提案されてきている。第 1 のモデルは本論で 取り上げる Della Tole 氏等の提案したムービングモデルであ る。Woodward 氏および Della Tole 氏は磁気記録テープの磁 気粒子間の相互作用の影響を示し ${ }^{2)}$ 、その改良方法として局 所的に発生する磁界と古典プライザッハモデルを結合したモ デルを提案した ${ }^{3)}$ 。このムービングモデルに関する報告は多
数あるが理論的な解析報告が多数を占め、プライザッハ図表 の分布を正規分布と仮定することでモデルを構築する方法 ${ }^{4)}$ 等が挙げられる。第 2 のモデルは Mayergoyz 氏の提案してい るモデルで、一次推移曲線群に加えて二次推移曲線群の実測 ループを要求している5) が、測定したデータの次数まで合同 特性は解消されるが実測ループの多さから実用的とは言えな い。第 3 のモデルは Kádár 氏等の提案しているプロダクトモ デルである。このモデルは古典プライザッハモデルの二次元 の図表を、磁化の影響を考慮した項および二次元分布を一次 元分布に置き換えた項との積と仮定することで、磁化自身の 影響を考慮したもの ${ }^{6)}$ である。このモデルは磁界方向の合同 性に問題点を残している。

第 1 のモデルであるムービングモデルの磁気双極子相互作 用を表す移動係数を決定する方法として、Della Torre 氏以外 にもその決定方法について実験的に求める方法が幾つか検討 されている。その一つにマイナーループ群の傾きから移動係 数を求める方法がある ${ }^{7)}$ が、精度的に問題があり最終的には 補正を加える等の後処理が加えられている。最近、この移動 係数を実験的に決定する合理的な方法が報告 ${ }^{8)}$ されているが、 そこでは具体的なムービングモデルへの適用は行っていない。 本論文では、この決定方法に従って、硬質磁性材料である環 状アルニコ磁石について、実験的に移動係数の決定を行って いる。さらに、プライザッハ分布関数のある集中した負の值 を持つ領域がその原因であると考えられるマイナーループの メジャーループ外に飛び出す現象について、今回実験的に決 定した移動係数を用いたムービングモデルが飛び出し現象を 解決できることを示す。最後に、ムービングモデルでは有効 磁界と磁化の関係を推定することはできるが、数值計算等で 必要となる外部磁界を直接求めることができないため、ムー 
ビングモデルの結果を外部磁界へ変換する方法を示す。この モデルによる推定結果と実験結果は良く一致し、移動係数の 実験的決定法の妥当性が確認された。

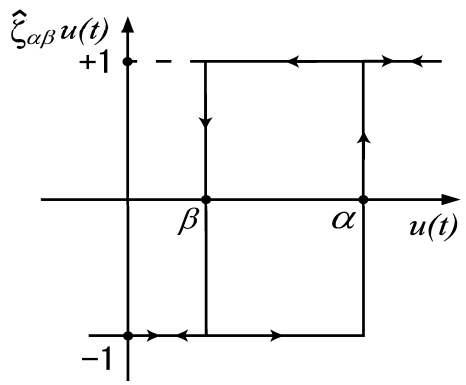

Fig. 1 An elementary hysteresis operator $\hat{\zeta}_{\alpha \beta}$.

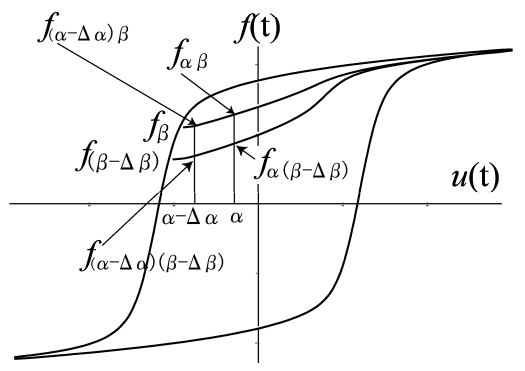

Fig. 2 Variables on first order reversal curves.

\section{Preisach モデル}

\section{1 モデルの原理}

古典プライザッハモデルは $u(t)$ を入力、 $f(t)$ を出力とする と (1) 式で表現することができる ${ }^{9)}$ 。

$$
f(t)=\iint_{\alpha \geq \beta} \mu(\alpha, \beta) \hat{\zeta}_{\alpha \bar{\beta}} u(t) d \alpha d \beta
$$

上式中の $\hat{\zeta}_{\alpha \beta}$ は基本ヒステリシス演算子と呼ばれ、Fig.1 に示すように、 $u(t)$ が増加している場合、 $u(t)=\alpha$ で -1 か ら+1 に反転し、減少する場合 $u(t)=\beta$ で+1 から -1 に反 転する性質を表す演算子であり、古典プライザッハモデルの 最小単位となる磁気双極子の性質を表している。Fig. 2 に示す 二本の一次推移反転曲線の上側の曲線について次のように定 義するものとする。

$$
F(\alpha, \beta)=\frac{1}{2}\left(f_{\alpha \beta}-f_{\beta}\right)
$$

このとき分布関数 $\mu(\alpha, \beta)$ は、

$$
\mu(\alpha, \beta)=-\frac{\partial^{2} F(\alpha, \beta)}{\partial \alpha \partial \beta}
$$

と表すことができる。

\section{2 測定装置}

一次推移反転曲線群の測定に用いた測定装置の概念図を Fig.3 に示す。測定方法は、始めに BH カーブトレーサーの直 流電源から磁性材料に巻かれた一次コイルに電流を流し磁界 を発生させる。次に磁界変化によって二次コイルに誘起され る電圧を $\mathrm{BH}$ カーブトレーサーの積分器に与え磁束密度に変 換する。この磁界と磁束密度を $\mathrm{AD}$ コンバータを通してコン ピュータに取り込むことで測定データが得られる。各種ルー プの測定はコンピュータから BH カーブトレーサーへ送られ る反転制御信号により実行される。

なお、本装置はドリフトを自動的に処理するようにプログ ラム制御しており、後述のムービングモデルの移動係数 $\gamma$ に 応じた有効磁界および磁束密度をリアルタイムで計算して反 転命令を発行するシステムを構築している。

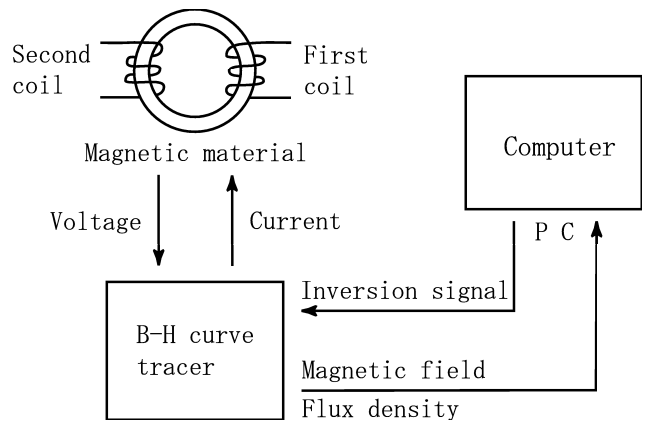

Fig. 3 Measuring equipments.

Table 1 Specifications of magnetic materials.

\begin{tabular}{|c|c|c|}
\hline Sample name & sample 1 & sample 2 \\
\hline Matcrial & AlNiCo & AlNiCo \\
\hline Shape & ring & ring \\
\hline Thickness $(\mathrm{mm})$ & 26.06 & 20.10 \\
\hline Outside diameter $(\mathrm{mm})$ & 51.30 & 61.80 \\
\hline Inside diameter $(\mathrm{mm})$ & 45.27 & 46.90 \\
\hline First turns & 2600 & 4300 \\
\hline Second turns & 30 & 30 \\
\hline Coercive force $(\mathrm{kAT} / \mathrm{m})$ & 8.75 & 12.7 \\
\hline
\end{tabular}

\section{3 予測計算に及ぼす負領域の影響}

本論では Table 1 に示す保磁力の異なる二種類の等方性アル ニコ磁石を対象としている。ここで Fig.4 に sample 1、 sample 2 について一次推移反転曲線群の測定データを示す。Fig.5 で 示す分布関数図を作成するために、正の外部磁界最大值から 負の外部磁界最大值までの範囲を 48 等分割し、それぞれ 48 個のマイナーループを測定している。各測定データの外部磁 界最大值はそれぞれ $3000 ̈$ e、4 $4000 ̈$ e である。これらマイナー ループの測定は正の磁界最大值から始まり、負の磁界最大值へ 向かって下降する途中の任意の分割点で反転し元の正の磁界 最大值で終了している。また、Fig.5 には上で求めた測定デー 

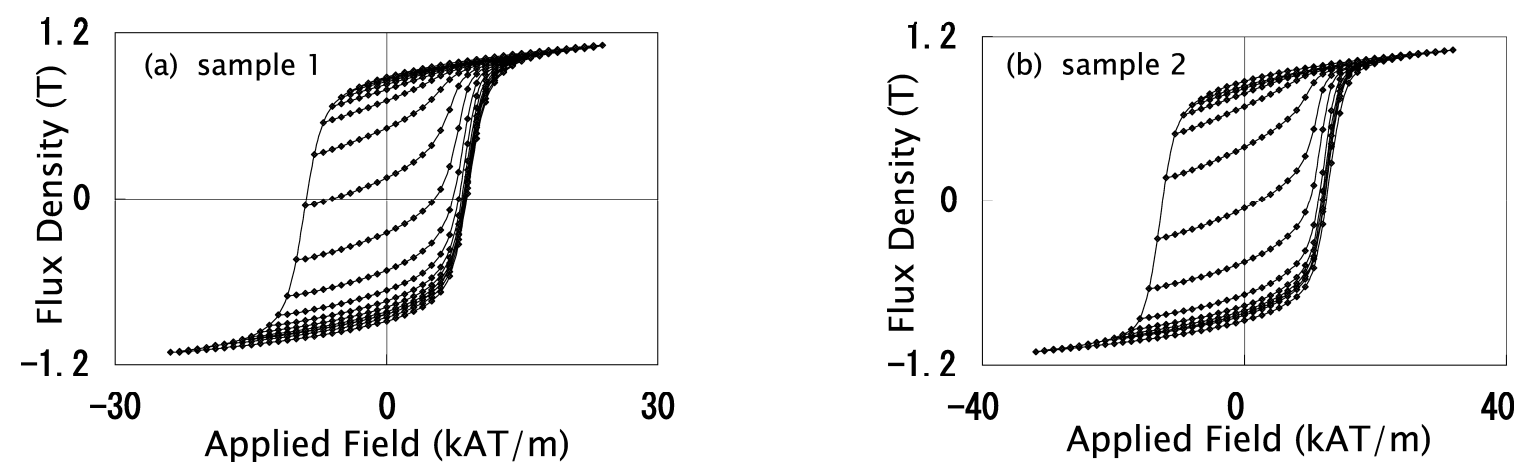

Fig. 4 Measured ascending first order reversal curves.
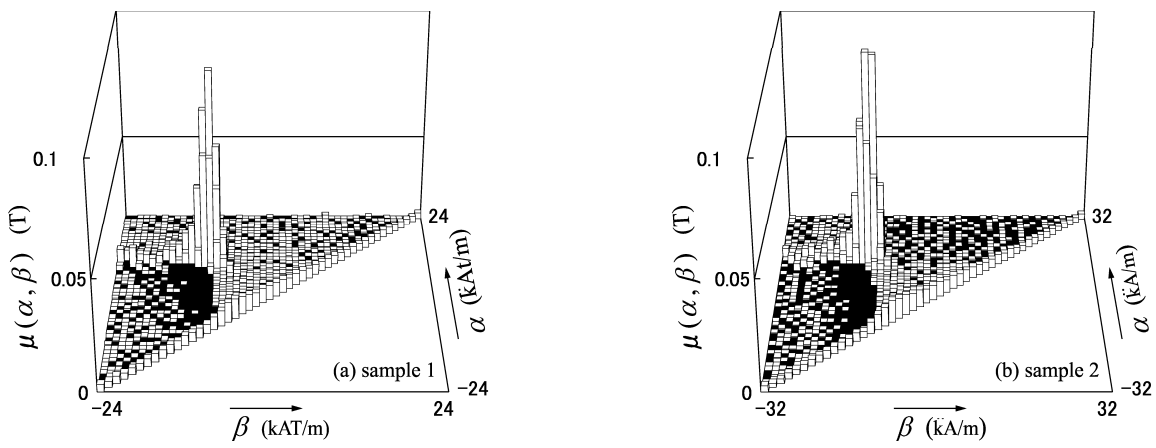

Fig. 5 Existence of the negative regions on distribution diagram.
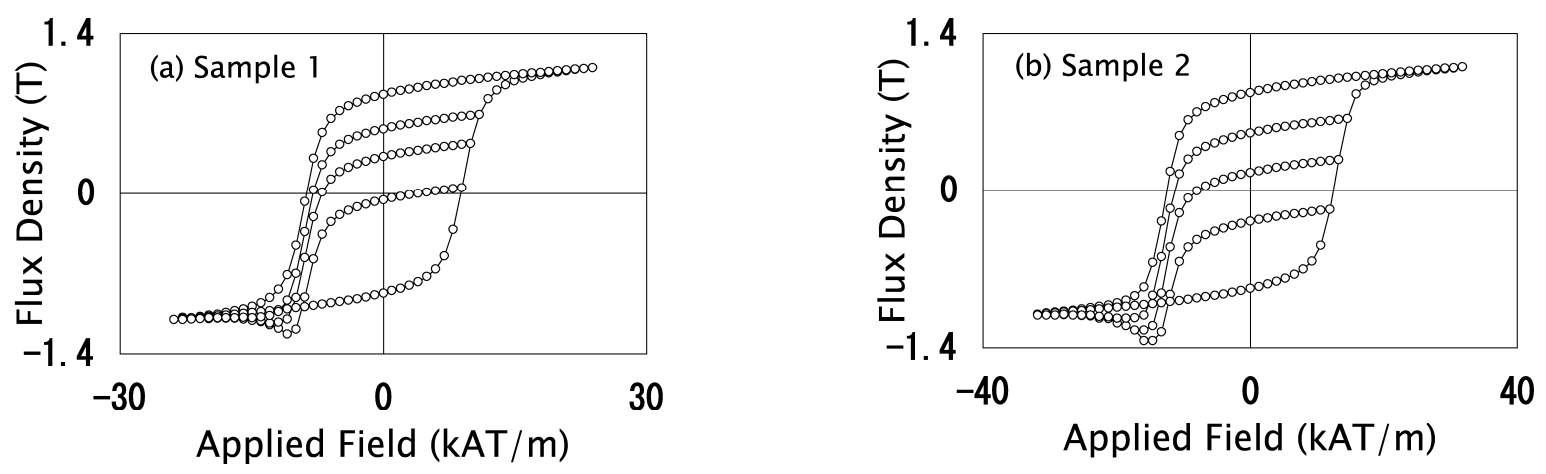

Fig. 6 Simulation for descending curves using the Preisach model.

タから決定したプライザッハ分布関数図を示す。データから 求めたプライザッハ分布関数では Fig.5 に示したように黒塗 りの部分に負の值が存在している。以降この負の值を負領域 と呼ぶことにする。なお、この分布関数の作成では出力とし て磁化の代わりに磁束密度を採用している。

次に負領域の存在理由について考察する。分布関数の值は 式 (3) で与えられているが、この式と Fig.2 の対応を考えて みる。 2 点 $\alpha$ および $\alpha-\Delta \alpha$ の微少区間 $\Delta \alpha$ における $f_{\alpha \beta}$ と $f_{(\alpha-\Delta \alpha) \beta}$ との差は式 (3) のうち $\alpha$ に関する偏微分に相当する 部分である。 $\beta$ および $\beta-\Delta \beta$ の 2 点で反転した二つの反転 曲線それぞれの $\Delta \alpha$ 区間の傾きの差分がさらに $\beta$ に関する偏 微分を加えたものに相当すると考えられる。隣接する二つの 反転曲線の傾きは下側が上側よりも大きくなるかほぼ等しい
ので、式 (3) で決定した分布関数の值は正となる。しかし逆 の場合の特性を持つことも考えられる。分布関数は磁気双極 子が磁界の上昇 $\alpha$ あるいは下降 $\beta$ のどの位置に存在するかを 示寸指標であることから、正の值をとると考えるべきであり、 一般にはそのような傾向にあるが、一次推移曲線の傾きが大 きく変化する場合には逆転現象が生じ大きな負の值を取る領 域が存在することになる。今回対象とした等方性アルニコ磁 石ではかなり広い範囲に大きな值の負領域が存在するが、珪 素鋼板やフェライトではこのような大きな負分布はほとんど 見られず、プライザッハモデルで今回のような問題は発生し ない。しかし保磁力付近で増分透磁率が大きく変化する材料 では今回のような大きな值の負領域が存在する可能性が予想 される。 


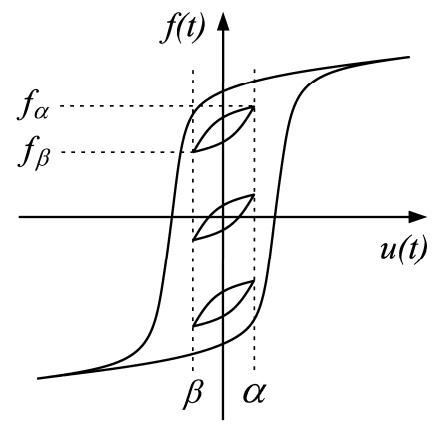

Fig. 7 Congruency property.

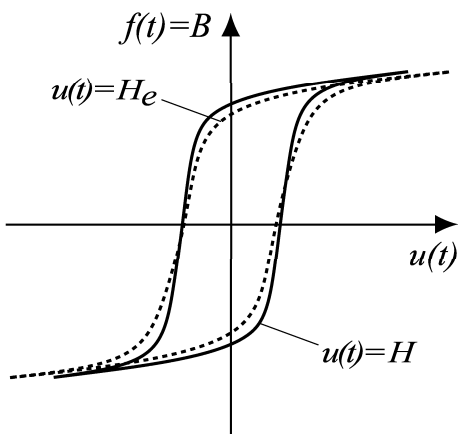

Fig. 8 Transformation of $B-H$ curve to the effective field.

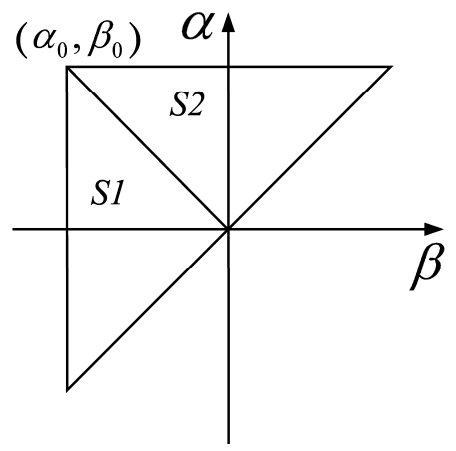

Fig. 9 Division of diagram by the line $\alpha=-\beta$ for the optimal decision of the moving factor $\gamma$. 布関数の対称性が崩れているためと考えられる。また磁界最 大值に対応する磁束密度より大きな值をとることについては 次のように考えられる。プライザッハモデルでは入力変化に 対する出力変化の計算を分布関数の足し合わせにより行って いる。分布関数が全て正の值の場合、分布関数図により表す ことのできる最大出力は磁界最大值に対する磁束密度の值で ある。しかし分布関数に負領域が存在すると、正の分布関数 の総和はこの值より大きな值となる。このため入力条件によっ ては出力が磁界最大值に対する磁束密度の值を超えることに なる。この問題は負の双極子数を減少させるか、負の密集領 域そのものを縮小あるいは分散させることで解決できること は明らかである。

\section{3. 負領域問題の解消法}

\subsection{Moving モデルの適用}

古典プライザッハモデルでは磁気双極子間に働く相互作用 は考慮されていない。そのため各双極子はそれぞれ独立して 存在し Fig.1 に示すように双極子一影響を及ぼすものは外部 磁界のみと仮定されている。Della Torre 氏はこの問題を解決 するために有効磁界

$$
H_{e}=H+\gamma M
$$

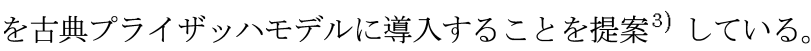
ここで $H$ は外部磁界、 $\gamma$ は移動係数、 $M$ は磁化である。この
ムービングモデルにおける有効磁界の導入は磁気双極子相互 の影響を考慮し結果的に Fig.7 に示すプライザッハモデル特 有の特徵である合同特性を解消寸ることとなったが、本論で 対象としている大きな負領域の発生原因も磁気双極子相互の 影響が考慮されていないモデルであるためと考えられるので、 有効磁界を導入した一次推移反転曲線群の測定データから磁 気双極子の分布関数図を作成しモデルの構築を行いその有効 性を確認する。

\section{2 移動係数 $\gamma$ の決定法}

有効磁界を適用した場合に生じる磁気特性曲線の変化を Fig. 8 に示す。実線は外部磁界 $H$ に対する磁気特性曲線であ る。一方、破線は有効磁界 $H_{e}$ に対する曲線であり、 $\gamma M$ の項 により磁気特性曲線が入力軸方向に引き伸ばされた形となる。 この有効磁界を考慮した一次反転曲線群のデータを測定する ためには、移動係数 $\gamma$ が未定であるので、まずこの定数を実 験的に決定する必要がある。幾種類かの $\gamma$ の值について一次 反転曲線群から求めたプライザッ八分布関数図の負領域の合 計值は $\gamma$ の増加とともに減少傾向を示すことは明確であるが、 分布関数図の対称性の観点から一概に増やすことはできない。 そこで理想とする分布関数図が $\alpha=-\beta$ に対して対称性を有 すると考えられることから、Fig.9 に示すように領域を二分化 

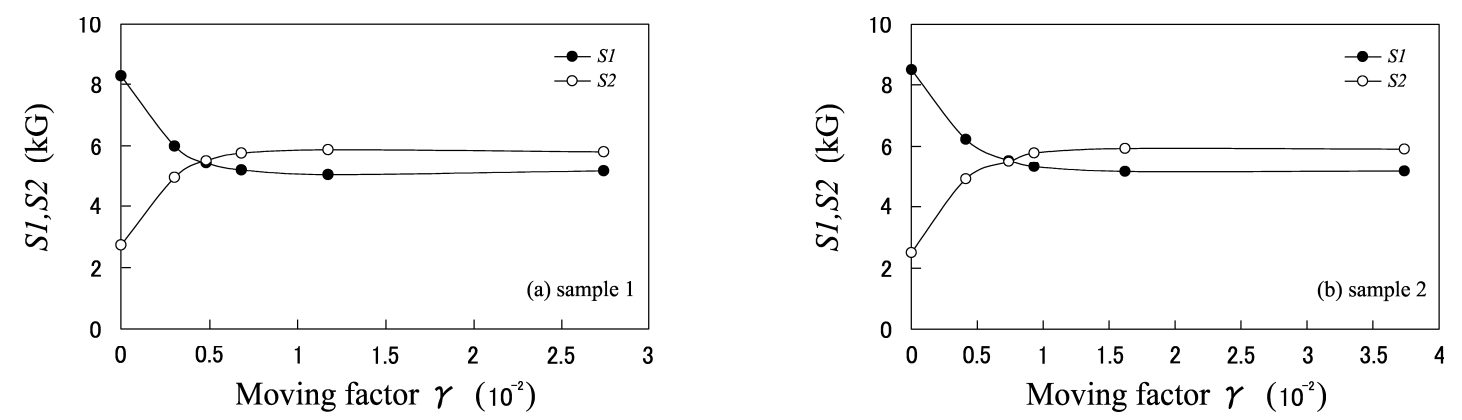

Fig. 10 Experimental determination for the moving factor $\gamma$.
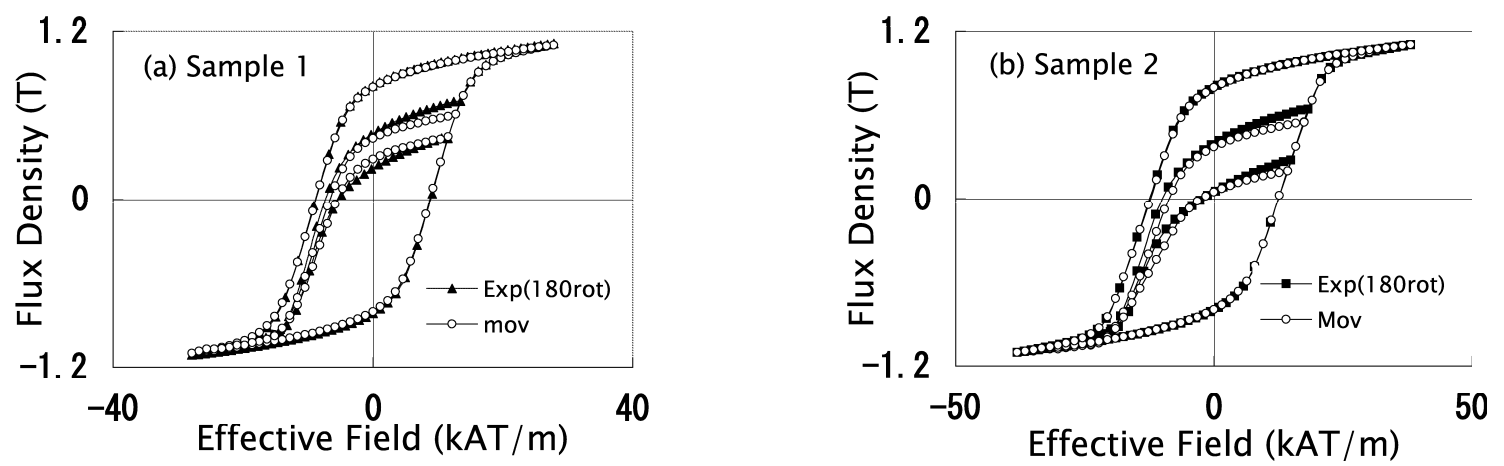

Fig. 11 Simulation of descending curves using the Moving model.

$\iota^{8)}$ 、分布関数図の $S 1$ 領域と $S 2$ 領域における磁気双極子の 総和が等しくなる $\gamma$ の值を最適値とする。

\subsection{Moving モデルによる予測計算結果}

ある $\gamma$ の值に対応した一次推移反転曲線群の実測データか ら分布関数図を作成し、二分化した $S 1, S 2$ の領域について磁 気双極子の総和を求め、この作業を $\gamma$ を変化させて繰り返し た結果を Fig.10 に示す。 sample 1、sample 2 の最大外部磁界 はそれぞれ 300 Öe、400Öe、分割数は 48 である。Fig.10より $\gamma$ の増加に伴い $S 1 、 S 2$ 領域における磁気双極子の総和が変 化していることがわかる。また sample 1 では $\gamma=0.0047$ 付近 で、 sample 2 では $\gamma=0.0074$ 付近で領域の対称性が保たれる という結果を得ることができた。この最適とされる $\gamma$ の值から 作成した分布関数図を用い、2.3 節で行った予測計算と同様に 一次推移曲線群の測定データに対し原点に点対称の反転シミュ レーションの結果を Fig.11 に示す。有効磁界による計算のた め最大磁界は sample 1 では 350 Öe、sample 2 では 480Öe で ある。比較のために一次推移反転曲線の測定データを有効磁 界に変換し原点で 180 度回転したデータを示す。測定值と算 定值の反転磁界の值は、保磁力近辺で変化が激しく、大きさ を揃えることが難しいのでほぼ同程度と考えられるものを示 す。これらデータから材料に点対称が成立していないことが 分かるが両者は比較的一致していると考えられる。Fig.11で はFig.6に示したようなマイナーループの落ち込みは見られ なくなり、負領域問題の解決に Moving モデルが有効である ことが確認できた。

\section{4. 外部磁界への適応}

\section{1 計算方法}

入力を有効磁界とすることで負領域のような磁化依存問題 を解消することが確認できたが、その入出力関係は有効磁界 に対する磁化あるいは磁束密度という制約が生じ、一方で実 際のヒステリシス現象は外部磁界に対する磁束密度の関係が 問題となる。このことからムービングモデルを数值解析等に 導入するためには、有効磁界から決定された分布関数図から 外部磁界に対応した出力が得られなければならい。そこで本 項では外部磁界にムービングモデルを適応させるための計算 方法を述べる。

ムービングモデルに外部磁界を直接与えた場合、付加項で ある $\gamma M$ の磁化 $M$ が未知数であるため有効磁界を決定でき ない。そこで (5) 式に示す関係式を用いて以下のような反復 計算によって磁束密度を決定している。

$$
H=\frac{H_{e}-\gamma B}{1-\gamma}
$$

入力 $u(t)=H$ に対する出力 $f(t)=B$ を求める場合には、初 めに Moving モデルへ任意の入力 $H_{e}$ を与え出力 $B_{\text {mov }}$ を得 る。ここで求めた出力を $B$ として $H_{e}$ と共に (5) 式に代入し て磁界を求め、これを $H_{m o v}$ とする。元の $H$ と $H_{m o v}$ との差 $d h$ について収束判定を行い、収束条件を満たすまで計算を繰 り返す。以上の反復計算により、入力 $u(t)=H$ に対する出力 $f(t)=B \fallingdotseq B_{\text {mov }}$ が得られる。 

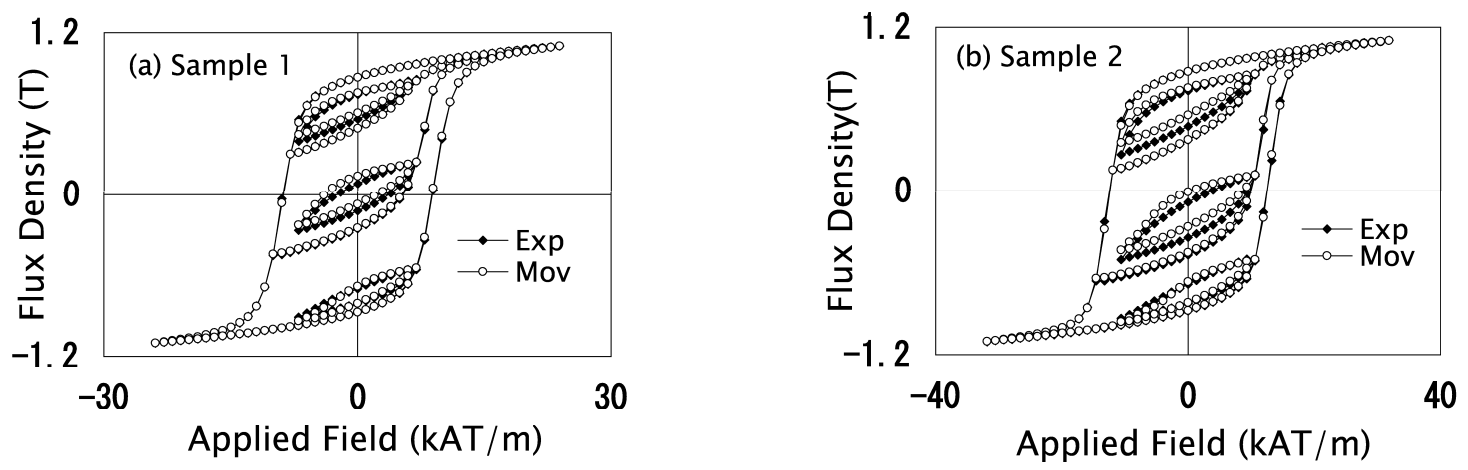

Fig. 12 Resolution of congruency property using the Moving model.

\section{2 計算結果}

提案した計算方法を用いてムービングモデルによる予測計算 を行った結果を Fig.12 に示す。 sample 1、sample 2 について モデルに与える最大外部磁界はそれぞれ $300 O ̈$ e、4 $400 O ̈ \mathrm{e}$ であ り、分布関数図は移動係数 $\gamma$ の最適值のものを使用している。 Fig.12 は合同特性について検討を行った結果であり、sample 1 では 87.5 Öe と -87.5 Öe の間で、 sample 2 では 133.3 Öe と -133.3Öe の間でそれぞれ反転させたマイナーループ群であ る。図中の 、○印はそれぞれ測定值と計算值を示す。古典プ ライザッハモデルでは同一磁界間で生成されるマイナールー プが全て同じ形状をとるのに対し、ムービングモデルによる 計算結果では磁化の影響が考慮されているためループの形状 が変化していることがわかる。計算精度についてはメジャー ループや一次推移曲線の結果はよく一致しているのだが、マ イナーループのような二次以上の推移曲線を計算した場合に 誤差が目立つ。この問題については次の原因が考えられる。移 動係数 $\gamma$ の決定に用いた二分化による分布関数図の磁気双極 子数は各領域で等しくなっているが、局所的に分布状態を比較 した場合に対称性が保たれているとはいえない。また保磁力 付近や磁化変化の大きな領域に存在する大きな值の磁気双極 子が+、ーいずれの状態にあるかで計算結果に大きな影響を 及ぼす点も一因かと思われる。以上を考慮すると、Fig.10に 示される交点の位置が $\gamma$ の最適值であるとは限らないとも考 えられる。この問題は測定データの分割数を増やすことで解 決されるが、今回使用した 48 分割を超える測定には膨大な時 間を要することから分割数に応じた比較領域の検討が必要と なる。

\section{5. まとめ}

古典プライザッハモデルにおける予測計算の精度や自由度 は本質的にモデル構築に使用した測定データに依存する。こ のため複数の反転を繰り返す高次の予測計算では実測值との
誤差が大きくなってしまう。さらに材料によっては分布関数 図内の負領域の存在によって有り得ない結果を引き起こすこ とが明確になった。今回、負領域の影響の大きな磁性材料に 関して古典プライザッハの不適合を明確に示し、その原因を 合同特性と同一の解決方法でその不適合を除去できることを 示すことができた。併せて移動係数の実験的決定法について の妥当性を示した。しかしながら、マイナーループの計算に ついては誤差が大きいことから、計算精度を向上させるため に移動係数 $\gamma$ の最適決定が必要となる。この決定法には領域 を分割する境界線のとり方や比較領域の位置、また測定デー タの分割数等を検討することが今後の課題と考えられる。

謝 辞 本研究を行うにあたり、測定実験において堀井研究室 の杉村徹さん、小野里美さんにご協力を頂きました。この場 をお借りして感謝の気持ちを申し上げます。

\section{References}

1) F.Preisach: Z. Phys.,94,277(1935).

2) J.G.Woodward, E.D.Torre: J. Appl. Phs.,31,56(1960).

3) E.D.Torre: IEEE. Trans Audio and Electroac.,AU-14,86(1966).

4) J.Oti, F.Vajda, E.D.Torre: J. Appl. Phs.,69,4826(1991).

5) I.D.Mayergoyz: J. Appl. Phys.,67,5373(1990).

6) G.Kádár: J. Appl. Phys.,61,4013(1987)

7) K.Okumura,S.Kato,A.Kishima: T.IEE Jpn.,108D,54(1988).

8) P.Postolache, M.Cerchez, IEEE Trans Magn,39,2531(2003).

9) I.D.Mayergoyz: J. Appl. Phys.,57,3803(1985). 